\title{
THE IMPLEMENTATION OF LAND ACQUISITION ACT 1960 AND ITS NEGATIVE IMPACT ON THE DEVELOPMENT OF WAQF (ENDOWMENT) LAND IN MALAYSIA
}

\author{
Mohamed Azam Mohamed Adil ${ }^{*}$ and Mohd Afandi Mat Rani ${ }^{* *}$
}

\begin{abstract}
The Land Acquisition Act 1960 has long been used in land acquisition law to take over land by force in Malaysia. This article attempts to identify the extent of implementation of land acquisition by the government based on the Land Acquisition Act 1960; whether it meets and is consistent with the Shariah, particularly involving Muslim waqf land. A few suggestions towards Islamisation of the act have been put forward to improve the Act by taking into account the principles and methods governing the Shariah so that every national development can be done in a more dynamic and comprehensive manner in tandem with modern needs.
\end{abstract}

\section{Introduction}

Land acquisition has always been considered a sensitive issue and it may cause controversies and create dissatisfaction amongst the people. The usual question put forward is the rationale of the land acquisition towards public interest, or whether the reason for land acquisition is really in tandem with the public interest. According to Article 13(1) of the Federal Constitution, no person may be deprived of property save in accordance with the law. The guarantees provided in the Federal Constitution are to ensure that private property rights are protected by law in Malaysia.

To meet its requirements, the authority has drawn up a law of land acquisition that has clear procedures so that all actions undertaken by the authorities are consistent with the rules and laws, particularly for land taken by force or without valid consent of the land owners, by taking into account the principles of adequate compensation as guaranteed in Article 13 (2) of the Federal Constitution. Even though land acquisition is legalised in Islam, the rule is not absolute. In addition, it involves trust property that benefits Muslim citizens. There are a few aspects that need to be analysed and refined without acting arbitrarily or taking easy steps that in the end will cause loss to the waqif and the trust holders. From other aspects, the right to preserve the benefits of waqif is included in the category of "specific rights". The right should never be put aside even though the basic rulings put "general rights" first rather than "specific right".

\section{Law of Land Acquisition in Malaysia}

According to Article 13 of the Federal Constitution, no person may be deprived 
of property save in accordance with law. Therefore, land acquisition by force is not opposed to Article 13 because the power and the process of land acquisition is done according to law under the Land Acquisition Act (LAA) 1960. If the land acquisition is against the law, the action is said to be illegal or void or could be subject to dispute. State Authority (SA) is the only entity that is given the power and right pertaining to State land which is within the State and the right to minerals and rocks that are located on and inside State land, as long as it has not been excluded specifically by the State Authority (SA). ${ }^{2}$

Section 2 of the LAA (1960) includes the King or Sultan, or the Governor and the Federal Territories of the King. The roles start from the decision of land taken until it is vested in him or her, or the land is withdrawn from the acquisition process. If the land is required for public development purposes such as building hospitals, schools, highways, bridges, dams, ports, airports, the Land Acquisition Act is also acted upon by the SA and by the Federal Government or any agencies that are in need of the land. Based on Article 13 of the Federal Constitution, and guarantees and provisions contained in the 1960 Act, acquisition of land by the government should not be construed as an act of plunder or that the government does not recognise the right of the people to their property. This is because the law requires that compensation be assessed at market price. This right is consistent with the concept of "adequate compensation" as guaranteed in Article 13 of the Federal Constitution. ${ }^{3}$

\section{The Land Acquisition Act 1960}

In essence, land is a matter of the State as enshrined in the Federal Constitution and it is within the jurisdiction of the executive of each State Government. However, Article 76(4) of the Federal Constitution allows Parliament to formulate a law of the land for the purpose of ensuring uniformity and equality of policies amongst the States. The law in question is the LAA 1960 (Act 486) amended in 1997. This Act came into force on October 13, 1960 for the whole of the Federation of Malaya. For Sabah, the law governing the acquisition of land is the Land Acquisition Ordinance, 1950, and in Sarawak it is the Sarawak Land Code 1958. The LAA 1960 was enacted by Parliament in accordance with Article 76(4) of the Constitution. Before the LAA 1960 became effective, there were eight written laws and they have undergone several amendments and modifications. They provide guidance on matters of land acquisition like land acquisition procedures, the parties involved, the compensation paid and the method for determining compensation. ${ }^{4}$

The LAA 1960 that has been practised in Malaysia is inherited from India (Land Acquisition Act (India) 1894). The main purpose of this Act as enacted is to establish uniformity of law in the States in connection with the acquisition of land 
by force. Besides, it is intended to cover the taking of lands owned by any person or body by force for public purpose or public facilities, evaluation, compensation for the land acquisition, and any matters arising from the acquisition of land. ${ }^{5}$

According to Salleh Buang, prior to the enactment of the Act, local laws related to land consists of four systems of law: ${ }^{6}$

(a) The Malay Customary Land Law (Undang-undang Tanah Adat Melayu);

(b) English Deeds System enforced in Penang and Malacca;

(c) Dutch Grants, applicable only in the vicinity of Kota Melaka; and

(d) Islamic Land Law (Undang-undang Tanah Islam).

With the existence of LAA 1960, the public interest will prevail over individual interest. Government development programmes can be done quickly and easily, even if the land affected is registered land and owned by individuals who may refuse to cooperate in the process of land acquisition. This shows that the existence of LAA 1960 is to facilitate the acquisition of land by the government. Through this uptake, it would eliminate the concept of use and enjoyment exclusively under Section 44 of the Land Code, and the concept of ownership cannot be denied under Section 340 of the Land Code. This is because in most cases the concept of buying and selling between individuals and the government failed to obtain agreement on the importance and value of land prices. Other than that, the acquisition will facilitate the exchange of the original conditions of land that occurs automatically.

\section{Land Acquisition by Force in Islamic Law and Its Application in the National Land Code}

Acquisition of lands by force that occurred during the time of the Prophet [pbuh] and practices implemented by the Companions were intended for public interest or maslahah 'ammah. Normally, dispossessed lands were taken for the construction or expansion of mosque sites, grave sites and the expansion of roads. The purpose and justification for taking over such land were not debated or disputed by Muslim jurists. Compulsion of the rulings was clear and not disputed by any parties. Indeed, the matters mentioned are set as fundamental needs of society in any country in the world. In fact, their absence would lead to hardship and inconvenience to the community and Muslims in particular. In addition, to a certain extent the level of needs is at the level of daruriyyat and no longer hajiyyat and tahsiniyyat. If the site of a masjid or graveyard is too small and can no longer accommodate the ever growing population, or there is a lack of roads for public access, and other basic necessities, in these cases, it becomes the responsibility of the authorities to provide proper facilities to ensure the comfort and happiness of the public. ${ }^{7}$ 
Previously, not many problems arose due to land acquisition because at that time there was abundant state-owned land and the population density was low. Most affected by the acquisition of land was government land and if there was any land involved, it could always be replaced by other land or by financial compensation. It is very different today, where land acquisition is not only for the purpose of constructing public facilities like roads, mosques and cemeteries. It is more for development projects for the sake of the development of country's economy. Amongst the projects are the constructions of factories, housing developments, shopping complexes and other profit-oriented businesses. Thus, nowadays, real estate investments are seen as more highly profitable business prospects than other forms of investment. ${ }^{8}$

An amendment to the 1960 LAA in 1991 brought major changes to the concept of land acquisition implemented by the government. ${ }^{9}$ It is different from what was carried out before the amendments were made. Even though the amendments only involved some particular sections, the impact on the land acquisition laws in the country is significant. The amendment raised a lot of controversies amongst the people who saw it as an act detrimental to landowners and a seizure of people's rightful property. Amendments to the 1960 LAA by the government today is to realise the government's intention in implementing a privatisation policy, which is expected to increase and accelerate the pace of economic growth through the contribution of public sector. The policy was announced by the former Prime Minister of Malaysia, Dato' Seri Dr. Mahathir Mohamad in 1993. ${ }^{10}$

The amendment to Section 3 of the LAA, 1960 provides that the powers over acquisition of land are given to the SA. The power conferred is absolute and final. This means that the power allocated to the State Authority to take any alienated land is not bound by or subjected to any terms and conditions other than those provided by the Act. All decisions made by them cannot be disputed and challenged in any court. According to Section 42 of the Land Code 1965, land is under the absolute jurisdiction of and belongs to the government. Therefore, the government of the SA is the only qualified party and authoritative on the eligibility and right to take any alienated land by force.

According to Section 3 (1) of the LAA 1960, individual property may be taken away by force by the government for public interest and the country's economic development. However, in today's reality, the government allows private bodies to acquire individuals' land. The entities who actually need the ownership of the land are institutions or bodies that want to develop and commercialise the land. This matter needs to be taken seriously as there is a threat that fraud and abuse of power can easily occur. This is because such practice will erode the positive meaning of public and national economic development and invites various arguments from the landowners. It also gives a long term impact on the 
development of waqf property in Malaysia. Amongst the matters raised is the question of land acquisition that can be made by anyone who is eligible to apply and the forms of economic development which are limitless and boundless. Other than that, the purpose of land acquisition or public interest is up to the government to decide. The worst phenomenon is that, whatever decision made by the SA, it cannot be disputed by any parties, be it the landowners or the court. ${ }^{11}$

Procedures adopted by the land administrator based on the LAA 1960 are seen to contrast with the concept of land acquisition in Islam. The confiscation of property by force in the country's land law is also found in Islam. However, what sets the two apart is that aspects of the implementation and practices being applied these days show a number of weaknesses and defects which must be taken into consideration to achieve justice for both the landowner and the agencies that want to take the land.

\section{Application of the Concept of Public Interest (Maslahah 'Ammah) and Public Purpose in Waqf Land}

The acquisition of waqf land in Islam, which is also based on the concept of maslahah puts stress on the aspect of the purpose and target of an action made and at the same time it takes care of the waqifs' benefits for which their right is taken by force. ${ }^{12}$ Therefore, when it comes to the implementation of the acquisition of waqf property by the government, it shall take into account several aspects before land acquisition is made as a basis or policy since it needs to be applied from the concept of maslahah in Islam. The policies include consideration of:

(a) The purpose of acquisition of waqf land is based on the urgent need in terms of religious, educational, economic and social criteria.

(b) The impact or implications of taking over the land itself to the waqif and trustee, and the benefits derived from the acquisition of land.

(c) Other alternatives that can be considered such as looking for another place in lieu of or other considerations in favour of both parties (the owner of the land and the taker of the land).

(d) The opinions and views of authoritative parties need to be considered as a study in determining the status / compulsory status.

Section 3(a)(b) of the 1960 Act provides for the same thing which is that the SA may acquire any alienated land for public purposes and it may also be given to individuals or bodies to carry out economic activities in the interest of or "beneficial" for economic development of the country. Furthermore, in Section 3(b) interpretation of "beneficial" is so broad and too general. Provisions contained in the section are not just for economic development but more than that. This also includes social cultural and religious activities. The meaning 
of economic development is provided in Section 3 (b) of the Act, which shall include the benefits for:

(a) Economic development of Malaysia;

(b) Economic development of parts of the people of Malaysia;

(c) Civilians as a whole; and

(d) Civilians of all ages ${ }^{13}$

Hence, it is not contrary to the policy of the Act where Section 13 (a) states that private land can be acquired by the Government for the purpose of erecting churches, temples, or other houses of worship. ${ }^{14}$ Although in practice until this study is done, there is no case of the SA applying Section 3 (a) for the purpose of building houses of worship other than Islam which involved waqf land. Even so, if the SA would like to take waqf land for the construction of churches or temples, this does not oppose or conflict with the Act, while any objection or protest is against the law (Section 36).

There is a change in the concept of land acquisition of after Section 2(3) of the Act was amended in 1991. The parties whose lands are taken cannot argue on the purpose of any acquisition made. The right to determine whether it is for public interest or individual interest belongs entirely to the SA. State Religious Councils (SRCs) have no right to question the purpose of any specific or general waqf land affected by land acquisition by the SA whether it is reasonable or not. SRCs have no jurisdiction in any acquisition law and anything related to it. In 1992, there was a suggestion made that the Act should be amended to disallow waqf lands (especially for masjid or madrasah) to be taken by the government for whatsoever purposes. Land administrators will not accept or entertain any objection applications from any parties wishing to object in term of the purpose of land acquisition. The then Deputy Minister of Land and Cooperative Development, Dr Goh Cheng Teik had advised the state government not to abuse their power to take over people's land for private projects. The ministry developed a revised proposal to the Council of the National Land Code (MKTN) in 1995. The ministry is willing to negotiate with the State government if there is land taken for development by the private sector and would ask for a report to be made to the ministry if there is such a case. ${ }^{15}$

The LAA of 1960 does not provide any section to land owners to void or prevent their land from being taken when Form A was gazetted. ${ }^{16}$ As explained before there is no precise definition of public purpose. The government is the only one who is qualified to interpret the qualification whether the acquisition is for public purposes or otherwise. The decision made by the government however, cannot be challenged by any parties in court. Therefore, the provisions made are in favour of land applicants to use the method of coercion in taking over lands 
especially involving non-urgent land development or simply taking an easy way to acquire strategic land for development. ${ }^{17}$

The Fiqh al-Islamy Council passed a few resolutions as a result of the $4^{\text {th }}$ Assembly which was held in Jeddah on the $6^{\text {th }}$ April 1988 pertaining to the forcible removal of ownership for the benefits of the public. One of the resolutions was that land taken by force from the owner cannot be used for the purpose of investment whether for the public or individuals. Based on this resolution, authorities should distinguish between the acquisition of land for public purposes and land intended for investment. ${ }^{18}$

\section{Standard of Benefit (Maslahah) in Waqf Land Acquisitions}

Rulings based on the mechanism of maslahah in all circumstances require clear guidelines or procedures. The benefits for human lives in this world are constantly changing over time. The effects of confusion and obscurity of this mechanism would affect the current rulings which are mostly built upon maslahah rulings. This concept has become the benchmark in applying the law either with stern prohibitions or allowing with certain conditions, or to take a moderate approach by relying heavily on decisions made by the government.

The acquisition of waqf lands for public interest must be solely for public interest (haqiqiyyah) or qat'iyyah rather than for interests that are wahmiyyah. The implementation of land acquisition made by the government for the purpose of constructing roads, hospitals, airports, mosques etc are obviously for the benefits of the people on the basis of necessity. Actions that have been taken here adhere to what is meant by maslahah haqiqiyyah or qat'iyyah as discussed by Muslim jurists. Acquisition can bring benefits to the public and the proposed projects are deemed necessary.

The lawful concept of land acquisition based on maslahah 'ammah discussed according to Shari'a rulings need to be taken into consideration to ensure the interest of all parties. Even though this approach is seen to mean the same as public purpose provided in the national civil land law, the interpretation between the two are different from each other, especially for waqf land with its own legal basis, as opposed to other general owned lands, in terms of usage and ownership rights. The concept of public purpose in Islam takes into account limitations and boundaries in accordance with Islamic legal maxims. Similarly, if there is a clash between two interests (maslahah), priority should be given to the public. ${ }^{20}$

\section{Contradiction between Benefit (Maslahah) and Harm/Damage (Mafsadah) in Waqf Land Acquisition}

As explained, land acquisitions by force are often exposed to abuse and misuse of power by interested parties. Therefore, a conflict exists between maslahah 
and mafsadah, which involves many aspects in the acquisition of waqf lands, especially in terms of the purpose of the acquisition and procedures when an acquisition is made.

Islam provides a clear guideline that state matters that lead to harm/damage or mafsadah shall be a priority from the aspect of goodness (jalb al-masalih). This means that in all cases of land acquisition, the matters that may lead to damage, difficulties or whatsoever negative implications in the future shall first be given consideration rather than the benefits from the actions. This procedure complies with the Islamic legal maxim that "dar'u al-mafasid awla min jalb al-masalih" (removing damage takes priority over promoting benefit). In the context of waqf land taken by force by the SA and not replaced with other land, it will lead to mafsadah not only to the waqif but also to Muslims in general. ${ }^{21}$

Besides, where there is a contradiction between these two elements, the method of tarjih (more appropriate and selected opinions) based on the concepts of rajih (stronger) and marjuh (weaker) can be implemented. These concepts are based on two aspects whether it is maslahah or mafsadah. The quantity of advantages and disadvantages becomes a measurement that determines the limit and boundary of the rulings between prohibition and command. For example, waqf land acquisition made for the purpose of building a public housing estate is categorised as maslahah wahmiyyah or in the public interest, seems to give profit and benefit the public. This implementation is initially seen to bring benefit to national economic development, but when examined in detail it appears to give long term detrimental effects to the alienated lands. Amongst the lawful conditions of land acquisition including waqf land is that the land acquired is for public use (al-kulliyyat) and should not benefit only a small number of individuals. ${ }^{22}$

From another aspect, the construction of housing estates undertaken by the government today is dominated by certain groups consisting of corporate members who earned enormous profits from selling the houses. The buyers of the houses are however, not from the low income group or people who are in need, but are high income people who can afford to buy the houses at a high price. Even in certain areas, non-Muslims take advantage to buy as many houses as possible just to acquire land.

\section{Requirements of Land Acquisition Application}

The Islamic method of land acquisition requires that only the government is entitled to take, or to seize ownership for public use. According to Dr. Bakr b. 'Abd Allah Abu Zayd, waqf lands that can be taken by force are bound to conditions or methods of Shariah rulings. If the lands acquired are not for the purpose of public interest such as giving them to foreigners to manage and develop, then such action is considered as "merciless", which is prohibited in Islam. ${ }^{23}$ 
According to Section 3 (b) of the Act, land application applies to anyone. It all depends on the State Land Authority (SLA) whether the applicants are Muslims or non-Muslims, corporate bodies, which may consist of locals or foreigners. The word "any person" brings about a major implication to individuals, companies or any eligible parties entitled to get lands. Any person here does not mean that it is specified to only eligible land owners, but also it may include parties who just use the land for economic development. Then Act does not state specifically who can apply to take any land. They have the right to own any land taken by force through the SA with reasons to develop economic activities on land held by the government, though originally they do not have any right to own land. ${ }^{24}$

Therefore, waqf land can be taken by any parties either individuals or corporations. To make any objection, obstruction or other actions that could disturb the acquisition of lands by force is considered an offence. Provisions contained in the Act are clearly in contrast to the methods of land acquisition in Islam. ${ }^{25}$ Eligibility to apply for a parcel of land in Islam should also be seen from a more practical and rational perspective. If waqf land is taken for luxury projects that are certainly profitable to particular parties, priority must be given to the major (kubra) maslahah rather than a small (sughra) maslahah. Waqf lands that usually bring benefit to the recipients normally come from the rich. Helping the poor is much better than helping the rich. This is because neglecting the poor is more harmful or engenders negative impacts. Therefore, the best approach is to prioritise the maslahah that results in adverse effects than the maslahah that has less adverse effects. ${ }^{26}$

Since there is no restriction and obstacle from the government, it is very worrying if waqf land also becomes forfeited assets because of the rapid changes over time and constant developments merely in the name of public interest, such as what is happening to the Malay Reserve Land (MRL). According to Ahmad Nazri Abdullah, in a period of 23 years (1947-1970), the Malays lost as much as 674,906 hectare of MRLs or on average 29,344 hectares per year. Although there is a provision to replace the acquisition of MRL, in reality it is not implemented at all. ${ }^{27}$

\section{Method of Determining Land Compensation}

Land acquisition by force with sufficient compensation has been agreed by majority fuqaha. ${ }^{28}$ Islam has laid down general rules in determining the amount of compensation that should be given to the landowner by emphasising the concept of justice (Al-Quran, Surah al-Nahl 16:90) and agreement between the two parties (al-rida bayna al-tarafayn). In the property valuation profession, to make a decision about the value of a property is not an easy task. ${ }^{29}$ The most accurate valuation and reasonable compensation is usually a result of a thorough, responsible and informed exercise. ${ }^{30}$ 
The specific methods and rules depend on siyasah al-syar'iyyah and the wisdom of the ruler. The authorities should make every possible effort to achieve these policies by not taking for granted or doing it half-heartedly as well as being irresponsible until it leads to injustice and cruelty to the parties whose land is acquired. ${ }^{31}$

The LAA of 1960 has allocated compensation and methods of compensation payment in the First Table of the LAA 1960 under Sections 12, 35, 46 and 47. The first table of the Act becomes a formal (written) regulation for valuers, land administrators and applicants in setting a fair value for compensation. Under the provision of the LAA 1960, there are some matters that need to be studied because they are against Shariah rulings practised by land administrators. The LAA 1960 is said to be a barrier to fair payment of compensation to landowners. According to the Deputy Director General of Valuation and Property Services Department (VPSD) Mani Usilappan, the LAA 1960 needs to be amended to enable fair compensation payments to be given to landowners whose lands are acquired for development purposes. The government also promised with the amendment of LAA 1960 (amendment 1997) that the LAA will become fairer and beneficial to the people. However, research shows that the matter of the value of compensation becomes disputed and the main factor for grievances of landowners when their land is involved in the acquisition. For example, land acquisition in Hulu Perak to widen the Gerik-Pengkalan Hulu route, is said to have had major differences between Malay and non-Malay landowners in term of land valuation. Malay landowners were paid between RM5,000 to RM6,000 compared to non-Malays, RM40,000 to RM50, 000. ${ }^{32}$

Land acquisition procedures adopted by the land administrator today do not facilitate the concept of bargaining between both parties in determining the amount of compensation or reimbursement. There is no consultation between the two sides to reach agreement. As a result, two different claims occur between the landowner and land applicant. The landowners surely would have demanded for high compensation and the land applicant would want to pay lower compensation. Section 12 of the LAA 1960 only gives full power to the land administrator to carry out a full inquiry to get the details needed as a basis to determine the award. Therefore, the compensation given often does not reach sufficient a amount and contrary to the market price. This is because the market price is the price owners accept willingly and without coercion from the buyer through bargaining. Section 37 of the LAA 1960, section 37 has given the power to landowners or SRCs to appeal to the court about the payment of compensation. However, the court cost is high and it takes a long time to settle, which brings loss to SRCs as transpired with the case of waqf land acquisition in the State of Melaka. 


\section{The Status of Waqf Land and the Rights to Demand Compensation}

The principle of al-ta 'bid or "sustainability" is explained by fuqaha in the chapter on conditions of sighah waqf. ${ }^{33}$ As was agreed upon by the majority of jumhur, determining or limiting the waqf land period implied denying the rulings of waqf. This is one of the principles that differentiate between waqf properties and other properties. In this case, there are views that waqf land holds "permanent" status as an absolute condition that cannot be tied to any specific period of time. The Shafi'i Madhhab suggests permanence as the main condition in giving properties to waqf. Therefore, removable properties cannot be endowed (waqf) unless the property remains part of permanent properties ('aqar). ${ }^{34}$

In Malaysia, some States designate cemetery and masjid sites under Section 62 NLC 1965 as public reserved land and are then regulated by the Religious Department or Religious Commissioner. In essence, the government or the SA gives reserve status to this land to avoid waqf land from changing to freehold land. If the government requires that land for development, the government has to bear a high cost to pay for compensation of land registered as freehold. But by categorising it as reserved land, the government only needs to cancel the reserved status and indirectly the lands become government-owned without it having to pay any compensation. Land laws in Malaysia deny the waqf land rights given by the government since it is known as tanah kurnia or bounty land. Whereas in property endowments in Islam, land given by the government for the purpose of religious activities is categorised as waqf irsad, which is also recognised as waqf..$^{35}$

It is suggested that the SA should look at the issue of land acquisition for development and give it serious consideration because of the concern that in future more and more types of waqf lands like masjid, surau and cemetery are being changed from their reserved status. The NLC 1965 also needs to be referred together to standardise it in all states to exclude mosque, surau and cemetery land from reserved status. This means all lands use for religious activities like mosque, surau and cemetery should be categorised as waqf land, which is also known as waqfirsad. Waqf irsad is state owned properties that were endowed by the government or the authority for the public interest and it has freehold status. ${ }^{36}$

It is time for all states to make changes by looking at the example introduced in the state of Kedah. More than 20 acres of mosque, surau and cemetery lands were taken by the government without paying any compensation. If the SA pays the compensation; surely the SRCs would be able to buy lands as replacement. Indirectly, this incident also invites negative perceptions from the public that SRCs do not defend mosque and Muslim cemetery lands until the lands are 
taken away by the government for the purpose of development. It may also allow people to come with an issue saying that SRCs also share profits by surrendering the land to the government. All these negative perceptions will affect the good name and credibility of SRCs in the eyes of the public. ${ }^{37}$

In this case, with reference to the provisions of Shari'a, if lands are endorsed for masjid/surau and cemetery by waqif to the government and reapplication is not made by SRCs, then the SA must pay the sum of compensation as the original value or more than the original value. Assets (compensation) will be included under the category of "waqf istibdal" replacing the first asset. All revenues and earnings must be applied to the same purpose as determined by waqif and in accordance to endowment rulings which do not allow any transaction done on it; that is it cannot be sold, given as gift or inherited. In the state of Johor, all lands that were given for religious purposes are put under the administration of Johor Islamic Religious Council (MAIJ). Therefore, reserved lands for public use like mosques, surau, cemeteries are put under the control of Johor Islamic Religious Council. Lands of these types need to be registered under the ownership of MAIJ. Similarly in Malacca, most of the tanah kurnia or bounty lands have been registered under the ownership of the Melaka Islamic Religious Council (MAIM).

\section{Alternative of Replacement of Land for Land (Tawid'bi al-'Aqar)}

The rulings of land acquisition by force in Islam are not only focusing on the benefits of the public. Even this is agreed amongst the jurists, that any land acquired shall be accompanied by replacement or valuation, better known in Arabic as ta'wid or qimah. Replacement either in the form of money or the same type is not determined by fuqaha because it depends on the needs and benefits of the ruler at any one time. ${ }^{38}$

In this case, it is the right of the property owners to get a just replacement or compensation ( $t a^{\prime}$ wid $a l$-adl). If the $t a^{\prime}$ 'wid is given in the form of money that brings justice to the owners, this is considered better and just to the landowners. However, not all situations can be resolved with money as replacement. It depends on the needs and wants of the landowners that are different from one another. Perhaps for individual landowners, they believe that replacement of money is a better option based on their needs. In our view, looking at the needs for land that is scarce and difficult to replace, $t a$ 'wid for waqf lands taken and compensated by government money, is deemed unjust.

In today's context, the concept of ta'wid is better known as compensation. Lands taken by force by the government are paid by money as the compensation to the landowners. Article 13(2) of the Federal Constitution provides that adequate 
compensation must be paid to the person deprived of property for the value of land taken. The amount of compensation must be paid as soon as possible after the land administrator conducts an investigation. Even though the compensation paid is deemed enough, but the concept of justice is sometimes overlooked. Land administrators who are assigned to take the land do not give any space to landowners to make a choice either to receive compensation money or other lands as replacement. ${ }^{39}$

This provision is actually contained in Section 15(1) LAA 1960 which gives full authority for land administrator discretion to negotiate to get agreement with the rightful person for compensation. Arrangements can be made either as:

(a) Replacement of compensation with money or;

(b) Replacement of the compensation partly with money and partly by other means.

Based on the provision of Section 15(1), the land administrators can use their discretion to either give compensation by money and land, or replace it with other land without any other compensation. In addition, the land administrator can also substitute it in the form of shares in a company or residence. Prior to materialisation of the LAA of 1960, the land administrator could use discretion to make arrangements with parties having interest, where acquired land would be replaced with another land.

The provision of section 15(1) of the Act is not applied fully by land administrators in carrying out their duty in land acquisition. The provision has not been debated by any party. There is a need to amend Section 15(1) of the Act. Thus, practically all lands whether they are individually owned or SRC's waqf lands, are compensated with money. The land administrators usually prefer the easier method by just making inquiry and pay the compensation with money. This is the simplest method practised by the land administrators, which might not be in favour to the land owners.

This is against the government policy that wants to develop waqf lands and encourage Muslims to waqf their property in order to increase the amount of waqf lands to facilitate economic development of Muslims as a whole. Therefore, looking at the current needs especially for waqf lands, it is important to give options to SRCs to determine the kind of compensations as provided in Section 15(1) of the LAA 1960. Legal department of the Headquarters of the DirectorGeneral of Lands and Mines (DGLMD) needs to examine and provide the extent of the appropriateness of this section so that it will stay relevant to current needs and provide benefits to all parties. ${ }^{40}$ 


\section{Implementation of Exchange of Land (Istibdal) to the Acquired Waqf Land by the State Authority}

Istibdal or waqf land exchange according to Shari'a is seen as one method or an alternative in solving waqf land acquisition by the SA which is implemented from the viewpoint of Imam Ahmad ibn Hanbal. Istibdal in this context is an alternative to the lawful rulings based on maslahah ammah. After waqf land is acquired by the SA, implementation of the istibdal mechanism is no longer an alternative, but it is obligatory to be implemented by the responsible party. ${ }^{41}$

If istibdal is not done by removing the original assets directly, an action giving permission to the SA to acquire waqf lands by force is against the methods and principles property endowment in Islam. This is because what is understood about lawful waqf land acquisition is that there is the concept of istibdal that can re-establish a second set of assets as waqf through replacement and exchange. With that, the action of waqf land acquisition by the SA does not contradict the hadith that waqf property cannot be sold, used for making hibah or inherited. ${ }^{42}$

Results of the study through an interview with the State of Terengganu DirectorGeneral of Lands and Mines (DGLM) found that there are a few approaches that are thought suitable for implementing the concept of istibdal without involving many parties. If it is seen from the scenario of difficulties to SRCs to acquire land as replacement, then SRCs should make a direct claim to the agency/company that acquires the land so that the acquisition requires replacement with land not money. In this case, the agency is given full responsibility to get other lands as a replacement. An agency that acquires land using the normal application method is provided under land laws with one of the three following mechanisms:

(a) To apply for government land from the SA.

(b) To buy private land from the proprietor/owner.

(c) To take any land by force through the legal process.

Through the first way, the agency will apply for government land from the SA. In this case, the effort of the agency to replace the waqf land needs to be paid attention to and supported by the SA. Moreover in some states, the Head of SRCs comprises the Chief Minister or Head of State of the respective States. Similarly, the State Executive Member or EXCO may also be appointed as Member of the Board of Directors which can take the initiative by providing land before any acquisition is made by the SA. The SA or state government should take this matter seriously because it involves the SRC's interest, which is institution under the administration of the state government.

If the first method cannot resolve the problem, the agency party needs to 
purchase a private property near to the waqf land. If both of these solutions are not available, the last way is to acquire land by force through provision in the LAA 1960 in the manner it is done to other owned lands. The decision to accept or reject the land to be replaced depends on the SRCs, and does not represent an automatic replacement. The outcome from an interview with the lands administrator suggests that they encourage SRCs to take these approaches to avoid the detrimental effects of declining numbers of waqf land due to development. In most cases land administrators do not agree to the acquisition of waqf lands and try hard not to involve them a land acquisition, unless they have no other choice but to act by force. ${ }^{43}$ In this case, claim or application must be made to a particular agency and not directly to the Land and Mineral Office (LMO). This is because LMO is a party that administrates and manages land acquisition or disposal. PTG has no financial provision to pay compensation for involved lands. Therefore, the agency or company must be responsible to find a suitable land for replacement.

If it involves Federal projects such as road construction, or road widening, airport development, etc, the agency needs to make an application to the DirectorGeneral of Lands and Mines Department (DGLMD) whereas application can be made at the state LMO for a State government project. There is the probability that land replacement for state government projects is easier because the land is owned by the state. DGLMD as well as LMO will provide support so that the application should be approved by the State government. If the land is individually owned, the agency needs to work hard and to discuss with the landowners to get an agreement to sell the land. If the landowner refuses and there are no other choices, the government will use the LAA 1960 by way of forced acquisition for the purpose of development. ${ }^{44}$

\section{Conclusion and Recommendation}

Islam has laid a clear and strong basis in the matters of revocation of individual property rights. This concept is discussed in the chapter of intiza' al-milkiyyah li manfa'ah 'ammah that refers to the concept of Maslahah which is taken from methods of fiqh as a mechanism to make it lawful to acquire ownership by force in Islam. However, the concept of istibdal fulfils the Shari'a need and requirement of current development that waqf lands can also be taken by force if there is an extreme necessity or darurah. All these must be done by fulfilling the standard and conditions contained in Shariah. ${ }^{45}$ Consequently, the main goal of Islam related to promoting national economic development is social justice.

- From a policy standpoint, policies and the implementation of property development in Malaysia needs to coordinate and adapt to Islamic values. 
- The LAA of 1960 which is the main vehicle for land acquisition in Malaysia and applied by land administrators needs to be studied, evaluated, and coordinated with Shariah methods, especially when it involves trust endowment property owned by Muslims.

- Islam forbids all actions that can interfere with others' rights or violations of ownership, which is not permitted by the Shariah. Such action is contrary to the principles that a person's ownership needs to be protected, preserved, and guaranteed in Islam.

- In an effort to improve the LAA 1960, whatever efforts and recommendations towards Islamisation of property laws need to be given serious consideration by interested parties so that it can sustain the needs of current development. ${ }^{46}$

\section{References}

Abu Zahrah, Muhammad (1971), Muhadarah fi al-Waqf, 2nd. ed., Kaherah: Dar alFikr al-"Arabi.

Ahmad Nazri Abdullah (1984), Melayu dan Tanah, Kuala Lumpur: Media Intelek Sdn Bhd.

Helmi Hussain (1999), Akta Pengambilan Tanah 1960, Suatu Huraian dan Kritikan, Bangi: Universiti Kebangsaan Malaysia

Ismail Omar (2002), Pelaburan Harta Tanah, 2nd.ed., Kuala Lumpur: Dewan Bahasa dan Pustak.

Mahmud Syamam (1988), Intiza' al-Milkiyyah li al-Maslahah 'Ammah, Mu'tamar Majma‘ al-Fiqh al-Islami, Vol. IV, No.2, Jeddah.

Mohd Afandi Mat Rani (2008), Pengambilan Tanah Wakaf Oleh Pihak Berkuasa Negeri: Analisis Menurut Hukum Syarak dan Aplikasinya di Malaysia, PhD Thesis, Department of Syariah and Law, Universiti Malaya Kuala Lumpur.

Al-Nisaburi, Imam Abi Husayn Muslim al-Hajjaj al-Qusyairi (1997), Sahih Muslim, Bab al-Waqf, Vol. 3. Mu'assasah 'Iz al-Din.

Roslan bin S. Ismail (2000), "Pengenalan Kepada Akta Pengambilan Tanah 1960", Kursus Perundangan dan Pentadbiran Tanah (Asas) untuk Pegawai-pegawai Pentadbiran Tanah Negeri Terengganu, di Hotel Seri Malaysia Kuala Terengganu, 31 Julai-3 Ogos 2000.

Al-Samhudi, Nur al-Din 'Ali b. Ahmad (t.t.), Wafa' al-Wafa, Vol.2, Beirut: Dar alKutub al-'Ilmiyyah.

Salleh Buang (1992), "Undang-undang Harta Tanah di Malaysia: Prospek dan Kemungkinan untuk Islamisasi”, Kertas Kerja Seminar Undang-undang Harta Tanah: Pendekatan Islam, organised by Institut Penilaian Negara (INSPEN) Kementerian Kewangan Malaysia.

Ridzwan Bin Ahmad (2004), "Metod Pentarjihan Maslahah dan Mafsadah dalam Hukum Islam Semasa", Prosiding Seminar Kebangsaan Usul Fiqh (SUFI), Kolej Universiti Islam Malaysia (KUIM), Institut Latihan Keselamatan Sosial KWSP (ESSET), Kajang Selangor, 15-16 December 2004.

Al-'Abbadi, 'Abd al-Salam (2000), Intiza' al-Milkiyyah al-Khassah li al-Manfa 'at 
al- 'Ammah, Mu'tamar Majma' al-Fiqh al-Islami, Vol. IV, No.2, Jeddah.

Siti Mashitoh Mahamood (2006), "Perundangan Wakaf dan Isu-isu Berbangkit", Konvensyen Wakaf Kebangsaan 2006, organised by Jabatan Wakaf Zakat dan Haji, di Hotel Legend Kuala Lumpur, 12-14 September 2006.

Suhaimi bin Hj Mamat (2001), "Peranan Agensi pemohon dalam Proses Pengambilan Tanah di Bawah Seksyen 3(1)(a) Akta Pengambilan Tanah 1960," Hotel Grand Continental Langkawi, Pada 5-7 November 2001.

Al-Zarqa, Syaykh Ahmad b. Syaykh Muhammad (1989), Syarh al-Qawa'id alFiqhiyyah, 2nd ed., Damsyiq: Dar al-Qalam.

Al-Zuhayli, Wahbah (1989), Usul al-Fiqh al-Islami, Vol.2, Damsyiq: Dar al-Fikr.

\section{List of Statutes}

The Federal Constitution

The National Land Code 1965

The Land Acquisiton Act 1960

The Local Government Act 1976

\section{List of Cases}

Syed Omar bin Abdul Rahman Taha Alsaqoff \& Anor lwn. Government of Johore, [1979]1 MLJ 49.

Yew Lean Finance Development (M) Sdn. Bhd. lwn. Pengarah Tanah dan Galian Pulau Pinang [1977] 2 MLJ 45.

\section{Reference of Newspapers}

Berita Harian, 24/9/1991

Berita Harian, 25/11/1996

Utusan Malaysia, 18 April 2001

\section{Interview}

Mr. Suhaimi Hj Mamat, Director, Terengganu Land and Minerals Department, 16 January 2012, Kuala Terengganu.

\section{Notes}

* Mohamed Azam Mohamed Adil is Associate Professor and Deputy CEO, International Institute of Advanced Islamic Studies (IAIS) Malaysia (Email: mazamadil@iais.org.my).

** Mohd Afandi Mat Rani, Senior Lecturer, Academy of Contemporary Islamic Studies (ACIS), Universiti Teknologi MARA, Shah Alam, Selangor (Email: mohdafandi@salam.uitm.edu.my).

1. The National Land Code, 1965.

2. Article 13 of the Federal Constitution, Sec. 40 The National Land Code, 1965; Sec. 2, the Land Acquisition Act (LAA) 1960.

3. Suhaimi bin Hj Mamat (2001), "The Role of Agency in Land Acquisition Process in Section 3(1)(a) the Land Acquisition Act (LAA) 1960," Briefing to Officers and Staff of Land Office and Board of Highways Malaysia, Grand Continental Hotel, Langkawi, 5-7 November 2001, p.2. 
4. Roslan bin S. Ismail (2000), "Introduction to the Land Acquisition Act (LAA) 1960", Legal and Land Administration Workshop for Terengganu Land Office, Seri Malaysia Hotel, Kuala Terengganu, 31 July -3 August 2000, p.2.

5. Helmi Hussain (1999), Akta Pengambilan Tanah 1960, Suatu Huraian dan Kritikan, Bangi: Universiti Kebangsaan Malaysia, p.24.

6. Salleh Buang (1992), "Undang-undang Harta Tanah di Malaysia: Prospek dan Kemungkinan untuk Islamisasi”, Seminar Undang-undang Harta Tanah: Pendekatan Islam, Organised by Institut Penilaian Negara (INSPEN) Kementerian Kewangan Malaysia, p.1.

7. Al-Samhudi, Nur al-Din 'Ali b. Ahmad (n.d.), Wafa' al-Wafa, Vol.2, Beirut: Dar al-Kutub al-'Ilmiyyah, pp.482-483.

8. Ismail Omar (2002), Pelaburan Harta Tanah, Kuala Lumpur: Dewan Bahasa dan Pustaka, p.19.

9. Roslan bin S. Ismail (2000), supra, p.2.

10. Mohd Afandi Mat Rani (2008), Pengambilan Tanah Wakaf Oleh Pihak Berkuasa Negeri: Analisis Menurut Hukum Syarak dan Aplikasinya di Malaysia, PhD Thesis, Shari'ah and Law Department, Universiti Malaya Kuala Lumpur, p.176.

11. Syed Omar bin Abdul Rahman Taha Alsaqoff \& Anor lwn. Government of Johore, [1979]1 MLJ 49.

12. Al-Syatibi, Abi Ishak (t.t.), Al-Muwafaqat fi Usul al-Syariah, Vol. 2, Beirut: Dar al-Kutub al-'Ilmiyyah, p.275.

13. Helmi Hussain (1999), supra, p.56.

14. Ibid.

15. Berita Harian, 25 Nov 1996.

16. Sec. 4, The Land Acquisition Act 1960.

17. Yew Lean Finance Development (M) Sdn Bhd v Pengarah Tanah dan Galian Pulau Pinang [1977]2 MLJ 45.

18. Mohd Afandi Mat Rani (2008), supra, p.212.

19. Al-Zuhayli, Wahbah (1989), Usul al-Figh al-Islam, Vol.2, Damascus: Dar alFikr, p.1029.

20. Al-Zarqa, Syaykh Ahmad b. Syaykh Muhammad (1989), Syarh al-Qawa'id alFiqhiyyah, Damascus: Dar al-Qalam, pp.187-188.

21. Ibid., pp.205-206.

22. Mohd Afandi Mat Rani (2008), supra, p.122.

23. Mahmud Syamam (1988), Intiza' al-Milkiyyah li al-Maslahah 'Ammah, Mu'tamar Majma' al-Fiqh al-Islamic, No., IV, Vol. 2, Jeddah, p.1089.

24. The Land Acquisition Act 1960.

25. The Land Acquisition Act 1960.

26. Ridzwan Bin Ahmad (2004), "Metod Pentarjihan Maslahah dan Mafsadah dalam Hukum Islam Semasa", (Proceeding National Seminar on Usul Fiqh (SUFI), Kolej Universiti Islam Malaysia (KUIM), 15-16 December 2004, Institut Latihan Keselamatan Sosial KWSP (ESSET), Kajang Selangor, p.346.

27. Ahmad Nazri Abdullah (1984), Melayu dan Tanah, Kuala Lumpur: Media Intelek Sdn Bhd, pp.217-218; Berita Minggu, 5 Sept. 2004.

28. Al-Abbadi, 'Abd al-Salam (2000), Intiza'al-Milkiyyah al-Khassah li al-Manfa'at al-Ammah, Mu'tamar Majma' al-Fiqh al-Islamy, No. IV, Vol.2, Jeddah, p.7.

29. Suhaimi bin Hj Mamat (2001), supra, p.2. 
30. Ismail Omar (2002), Pelaburan Harta Tanah, supra, p.19.

31. Ismail Omar (2005), "Tidak Mengambil Berat Pentadbir Tanah dalam Prosedur Pengambilan Tanah", Working Paper in Standardization of Land Acquisition, Costa Rica Port Dickson, Negeri Sembilan, 3-4 March 2005.

32. Utusan Malaysia, 18 April 2001; Berita Harian, 24 September 1991.

33. Abu Zahrah, Muhammad (1971), Muhadarah fi al-waqf, Cairo: Dar al-Fikr al'Arabi, p.63.

34. Mohd Afandi Mat Rani (2008), supra, p.29.

35. Sec. 62, The National Land Code 1965.

36. Siti Mashitoh Mahamood (2006), "Perundangan Wakaf dan Isu-isu Berbangkit", Konvensyen Wakaf Kebangsaan 2006, Anjuran Jabatan Wakaf Zakat dan Haji, Legend Hotel, Kuala Lumpur, 12-14 September 2006.

37. Mohd Afandi Mat Rani (2008), supra, p.241.

38. Al-Abbadi, 'Abd al-Salam (2000) supra, p.33.

39. The Federal Constitution, Sec. 12(1) LAA, 1960.

40. Sec. 15(1), The Land Acquisition Act 1960.

41. Mohd Afandi Mat Rani (2008), supra, pp. 135-148.

42. Al-Nisaburi, Imam Abi Husayn Muslim al-Hajjaj al-Qusyairi (1997), Sahih Muslim, Bab al-Waqf, .Vol. 3. Mu'assasah 'Iz al-Din, p.453.

43. Interview with Mr. Suhaimi Hj Mamat, Director, Terengganu Land and Minerals Department, 16 January, 2012, Kuala Terengganu.

44. The Land Acquisition Act 1960.

45. Mahmud Syamam (1988), supra, p.1089.

46. The Land Acquisition Act 1960. 